\section{Effects of Mulching and Preemergence Herbicide Placement on Yellow Nutsedge Control and Ornamental Plant Quality in Landscape Beds}

\author{
Yan Chen ${ }^{1,3}$, Ronald E. Strahan ${ }^{2}$, and Regina P. Bracy ${ }^{1}$
}

AdDITIONAL INDEX wORDs. Cyperus esculentus, EPTC, pine nugget, pine straw, s-ethyl dipropylthiocarbamate, shredded cypress, weed management

SUMmaRY. Yellow nutsedge (Cyperus esculentus) is one of the most troublesome and widespread perennial weeds infesting landscape plantings in the United States. Few selective herbicides are available for managing this weed. A combination of organic mulch with preemergence herbicide may improve control efficacy at tuber emergence and reduce the need for subsequent postemergence applications. However, limited information is available on potential interactions between herbicide placement and mulching and their effect on yellow nutsedge control and landscape plant growth and quality. In this study, control efficacy of preemergence herbicide s-ethyl dipropylthiocarbamate (EPTC) applied at 0,4 , or $6 \mathrm{lb} /$ acre above or under pine straw, pine nuggets, or shredded cypress mulches were evaluated in landscape beds infested with yellow nutsedge and planted with 'Mystery' gardenia (Gardenia jasminoides), 'Stella de Oro' daylily (Hemerocallis), and 'Big Blue' liriope (Liriope muscari). Pine nuggets provided greater yellow nutsedge control compared with shredded cypress during the first 6 weeks after treatment (WAT) in mulch-alone plots. All mulch-alone plots had similar yellow nutsedge shoot densities and were $40 \%$ to $60 \%$ less than untreated bare soil plots from 6 to 12 WAT. Control efficacy was greater when EPTC was applied under mulch compared with above-mulch applications regardless of mulch products. In addition, EPTC at low rate resulted in similar control as high rate when applied under mulch. No injury was observed on any ornamental plants treated with EPTC. Mulching improved growth, flowering, and overall visual quality of gardenia, but reduced number of flowers in daylily and aboveground biomass in liriope at some sample dates though their visual qualities were unaffected. Based on these preliminary data, EPTC applied preemergence before mulching a new landscape bed or replenishing an existing bed can improve yellow nutsedge control without injuring selected ornamental plants.

$\mathrm{Y}$ ellow nutsedge is one of the most troublesome and widespread perennial weeds in managed landscapes in the United States (Gao et al., 1999; Wilcut et al., 1991). Its upright growth habit and pale green leaf color are a prominent distraction and reduce aesthetic quality of landscape beds. It is found in nearly all soil types and thrives in irrigated areas and tends to become established where other weeds are controlled. It is fast growing. A single plant is capable of producing 19,000 to 22,000 additional tubers and

We thank Gowan USA Turf \& Ornamental Co. for providing Eptam 5G.

${ }^{1}$ Hammond Research Station, Louisiana State University Agricultural Center, 21549 Old Covington Highway, Hammond, LA 70403

${ }^{2}$ School of Plant, Environmental, and Soil Sciences, Louisiana State University Agricultural Center, 104 Sturgis Hall, Baton Rouge, LA 70803

${ }^{3}$ Corresponding author. E-mail: yachen@agcenter.lsu. edu.
1700 to 3000 aerial shoots in 1 year (Ransom et al., 2009). The numerous carbohydrate-storing tubers can be distributed from 2 to 14 inches below soil surface and are viable for 2 to 4 years or longer (Stoller and Sweet, 1987).

Hand removing is time-consuming, expensive, and inefficient. Landscape professionals rely on postemergence control by directed spray of nonselective herbicide such as glyphosate (personal communications with landscape contractors in Louisiana). Repeated applications are often required for postemergence herbicides and may cause ornamental plant injury if spray drift occurs. Selective preemergence herbicides registered for yellow nutsedge control in landscapes include dichlobenil, dimethenamid-P, and metolachlor. However, control efficacy varies due to application rate, timing, tuber depth, stage of dormancy, and environmental factors (Banks, 1983; Patton and Daniel, 2012).

Applying selective preemergence herbicides in combination with mulching may improve control efficacy and reduce the need for subsequent postemergence applications. Benefits from organic mulches are well established and a wide variety of mulch products are available for landscape use (ChalkerScott, 2007). Organic mulches reduce weeds by inhibiting germination and suppressing growth (Duryea et al., 1999; Skroch et al., 1992). Control effects are greater when mulch is fresh, possibly because of higher content of allelochemicals (Duryea et al., 1999). Coarser mulches outperform finer textured mulches (Billeaud and Zajicek, 1989). Improved herbicide efficacy was reported from studies where herbicides were sprayed onto mulches, mixed, and broadcast over nursery containers (Case et al., 2005; Samtani et al., 2007). However, effects of herbicide placement on yellow nutsedge control efficacy, and phytotoxicity on ornamental species in landscape settings, have not been reported.

EPTC is a thiocarbamate herbicide registered for preemergence control of certain annual grasses, broadleaf weeds, and perennial weeds, including yellow and purple nutsedge (Cyperus

\begin{tabular}{llll}
\hline $\begin{array}{l}\text { Units } \\
\begin{array}{l}\text { To convert U.S. to SI, } \\
\text { multiply by }\end{array}\end{array}$ & U.S. unit & SI unit & $\begin{array}{l}\text { To convert SI to U.S., } \\
\text { multiply by }\end{array}$ \\
\hline 0.1 & $\mathrm{bar}$ & $\mathrm{MPa}$ & 10 \\
0.3048 & $\mathrm{ft}$ & $\mathrm{m}$ & 3.2808 \\
0.0929 & $\mathrm{ft}^{2}$ & $\mathrm{~m}^{2}$ & 10.7639 \\
3.7854 & $\mathrm{gal}$ & $\mathrm{L}$ & 0.2642 \\
2.54 & inch $(\mathrm{es})$ & $\mathrm{cm}$ & 0.3937 \\
48.8243 & $\mathrm{lb} / 1000 \mathrm{ft}^{2}$ & $\mathrm{~kg} \cdot \mathrm{ha}^{-1}$ & 0.0205 \\
1.1209 & $\mathrm{lb} / \mathrm{acre}$ & $\mathrm{kg} \cdot \mathrm{ha}^{-1}$ & 0.8922 \\
28.3495 & $\mathrm{oz}$ & $\mathrm{g}$ & 0.0353 \\
7.4892 & $\mathrm{oz} / \mathrm{gal}$ & $\mathrm{g} \cdot \mathrm{L}^{-1}$ & 0.1335 \\
$\left({ }^{\circ} \mathrm{F}-32\right) \div 1.8$ & ${ }^{\circ} \mathrm{F}$ & ${ }^{\circ} \mathrm{C}$ & $\left(1.8 \times{ }^{\circ} \mathrm{C}\right)+32$ \\
& & &
\end{tabular}


rotundus) in a wide range of crops, including landscape ornamentals. Soil incorporation of EPTC before yellow nutsedge emergence provided between $78 \%$ and $100 \%$ control vs. $49 \%$ and $57 \%$ control from glyphosate applied postemergence in field ornamental production (Ahrens, 1994). The emulsifiable concentrate formulations are highly volatile and soil incorporation or injection is required for effective application (Baker et al., 1996). The granular formulation Eptam 5G (Gowan USA Turf \& Ornamental Co., Yuma, AZ) provides slightly or moderately greater control relative to the liquid formulations when applied to soil surface. Residual effects of granular EPTC under or above organic mulch are unknown. Increases in organic matter increase adsorption of EPTC and may therefore reduce its leaching. Applying to soil then covering with mulch may help reduce volatilization and extend residual effect. In addition, mulches also provide an organic bonding material thus helping the herbicide reside longer. Alternatively, organic mulches may improve the microenvironment of soil microbial community, thereby increasing microbial activity (Siczek and Frac, 2012), the primary factor in EPTC breakdown in soils.

Another major benefit of mulching is improved ornamental plant establishment and growth (ChalkerScott, 2007; Maggard et al., 2012). Numerous studies have demonstrated that improved water retention and reduced weed growth are correlated with increased root growth of ornamental plants in mulched landscape beds (Chalker-Scott, 2007). Green and Watson (1989) reported increased crown and root development and stem diameter on bare root sugar maples (Acer saccharum) under a 2 -inch layer of wood chips and composted leaves. Hensley (1990) found that 3 inches of hardwood bark mulch increased height and stem diameter of southern magnolia (Magnolia grandiflora). However, effects of mulching are dependent on plant species, mulch depth, and site conditions. Mulching may not benefit certain plant species. Pine bark mulch had no significant benefit to five arid land shrub species (Hild and Morgan, 1993). Billeaud and Zajicek (1989) reported that mulches over 4 inches deep tended to inhibit plant growth, although optimum depth was dependent on mulch materials used. Even when mulches were applied at appropriate depths, negative effects of mulching on plant growth have been reported and were possibly caused by 1) potential allelopathic effects (Cregg and Schutzki, 2009), 2) high carbon:nitrogen $(\mathrm{N})$ ratio that can lead to $\mathrm{N}$ immobilization by soil microorganisms (Pickering and Shepherd, 2000), and 3) water interception when irrigation amount is light, thus causing a drier root ball and greater tree stress (Gilman and Grabosky, 2004).

An integrated weed management program that includes mulching and preemergence herbicides may minimize the need for postemergence herbicide applications. Objectives of this study were to evaluate effects of mulch and preemergence herbicide EPTC on yellow nutsedge control efficacy and growth and quality of three selected ornamental plant species in experimental landscape beds.

\section{Materials and methods}

The experiment was conducted at Louisiana State University Agricultural Center (LSUAC) Hammond Research Station, Hammond, LA (lat. $30^{\circ} 32^{\prime} \mathrm{N}$, long. $91^{\circ} 9^{\prime} \mathrm{W}$, U.S. Department of Agriculture Hardiness Zone $8 \mathrm{~b}$ ). Field plots were prepared in mid-Feb. 2006. Site was sprayed with glyphosate (RoundupPro Concentrate at $1.6 \% \mathrm{v} / \mathrm{v}$, Monsanto Co., St. Louis, MO) to eliminate existing vegetation. Native topsoil is a Cahaba sandy loam with $57 \%$ sand, $30 \%$ silt, $13 \%$ clay, and $1 \%$ organic matter. Soil analysis indicated (in milligrams per liter): 37 phosphorus, 53 potassium, 499 calcium, and 127 magnesium and $5.3 \mathrm{pH}$ in native soil (LSUAC Soil Testing and Plant Analysis Laboratory, Baton Rouge, LA).

BED PREPARATION AND PLANTING. Four raised beds, each $110 \mathrm{ft}$ long $\times$ $5 \mathrm{ft}$ wide, were made by rototillerincorporating a 4 -inch-thick layer of bedding mix [mixture of green-waste compost, rice hull, and top soil (Natural Resources Recovery, Baton Rouge, LA)] and dolomitic limestone (70 lb/ $1000 \mathrm{ft}^{2}$ to raise soil $\mathrm{pH}$ to 6.5 ) into top 6 inches of soil. Each raised bed was divided into 18 treatment plots ( $4 \mathrm{ft}$ long $\times 5 \mathrm{ft}$ wide). A $2-\mathrm{ft}$ alleyway was left between individual plots, and weeds in these areas were controlled with glyphosate $(1.6 \% \mathrm{v} / \mathrm{v}$ of RoundupPro Concentrate) during the experiment.

Experimental design was an unbalanced randomized complete block design with four replications (O'Rourke et al., 2005). Treatment structure consisted of three EPTC rates $(0,4$, or $6 \mathrm{lb} /$ acre) by four mulch types (bare soil, pine nugget, pine straw, and shredded cypress) and by two herbicide placements (above or under mulch). Mulch- and herbicide-alone treatments were used as controls. Mulch-alone treatments were treated with one of the three organic mulches, but received no herbicide. Herbicidealone treatments were treated with EPTC at 0 (untreated bare soil), 4 or $6 \mathrm{lb} /$ acre on bare soil. Because herbicide placement as a treatment factor was missing from these controls, the experimental design was "unbalanced." The 18 treatment combinations were randomly arranged within each raised bed (replication).

Fifteen yellow nutsedge tubers (Azlin Seed Service, Leland, MS) were planted per square foot $\approx 1 / 2$ to 1 inch deep in field plots on 1 Mar. 2006. Three landscape ornamental species ('Mystery' gardenia in 1-gal pots, 'Stella de Oro' daylily and 'Big Blue' Liriope in 4 -inch pots) were transplanted to field plots on 6 Mar. 2006. One gardenia was planted in the center of the plot with two daylilies and two liriope plants randomly planted around it. Microsprayer sprinklers (11 gal/h, Vari-Jet; Antelco Corp., Longwood, FL) were set to deliver 2.75 gal of water to each plot at each watering. Irrigation was scheduled three times per week for the first 4 weeks after planting and then reduced to twice per week. An irrigation controller (ESP-4SMTe; Rain Bird, Azusa, CA) was programmed to suspend watering when rain reached $1 / 2$ inch.

Treatment application. Granular EPTC was broadcast $3 \mathrm{~d}$ after transplant as a preemergence treatment over the top of the ornamental plants using a handheld spreader. Plots were irrigated after applications to help dissolve the material into soil as indicated on product label. Three mulch products commonly used in the southeastern region were applied before or immediately following EPTC application. Mulch-alone treatments were mulched at the same time. After 
mulching and herbicide treatments, controlled release fertilizer $14 \mathrm{~N}-$ 4.2P-11.6K (8- to 9-month southern, Osmocote; Scotts Co., Marysville, $\mathrm{OH}$ ) was broadcast over the plots at an $\mathrm{N}$ rate of $2 \mathrm{lb} / 1000 \mathrm{ft}^{2}$.

Mulch treatments consisted of pine straw [needles from slash pine (Pinus elliottii); Custom Pine Straw, Branford, FL], pine bark nugget [bark and some wood from slash pine and loblolly pine (Pinus taeda); Louisiana Soil Products, Ruston, LA], and shredded cypress [bark and some wood from bald cypress (Taxodium distichum); Corbitt Manufacturing Co., Lake City, FL]. These mulch products were selected because of their consistent availability in the southeastern region. All mulch products were fresh and undyed. Size composition (by volume) of each mulch product was determined by separating particles $<1$ inch, 1 to 2 inches, and $>2$ inches. The majority of pine nugget and shredded cypress had a diameter of 1 to 2 inches, but more shredded cypress were $<1$ inch (Table 1). Bulk density (weight per volume) was determined using procedures described by Bilderback and Fonteno (1993). Because of potential differences in settling among mulches, a small trial was conducted before this research to calculate the approximate amount of products needed to maintain a 3 -inch-thick layer after four weeks of settling. A 3-inch depth was selected based on practices of regional landscape professionals.

Soil temperatures and moisture were recorded by soil moisture sensors (5TE; Decagon Devices, Pullman, WA). Sensors were buried 1 inch below the surface of bedding mix on the south side of the gardenia plants in four plots: three mulched with one of the three mulch products and an untreated bare soil plot. Data were recorded every $30 \mathrm{~min}$ from
0700 to $0800 \mathrm{HR}, 6$ to 13 June 2006. Light intensity at the surface of bedding mix under each mulch type or at the surface of bare soil was recorded by an external quantum light sensor (AccuPAR, Decagon Devices) at $1200 \mathrm{HR}$ from 6 to 13 June 2006.

Data collection. Yellow nutsedge control efficacy was evaluated by shoot density and visual estimation of percentage control. Yellow nutsedge shoots in each plot were counted at $2,4,6,8,10$, and 12 WAT. Shoot density was calculated by dividing this count by plot size $\left(20 \mathrm{ft}^{2}\right)$. At 17 WAT, yellow nutsedge shoot numbers were too high to count in untreated bare soil plots, and control efficacy was estimated visually by a weed scientist by comparing treated plots with untreated bare soil plots using a scale from $0 \%$ to $100 \%$ (complete control).

Plot aesthetic quality (PAQ) was a subjective rating considering yellow nutsedge presence and was assessed at 12 WAT for mulch-alone and herbicide + mulch plots. Herbicide-alone plots were not rated for PAQ because of a significant difference in aesthetic quality observed between mulched and unmulched plots. PAQ had a scale from 1 to 10 , where 1 to 3 represented the most severe weed infestation as seen in untreated bare soil plots, ratings from 4 to 5 indicated poor plot quality with severe weed infestation, ratings from 6 to 7 represented below-average quality with unacceptable weed presence, 8 indicated average quality with some weeds, 9 represented good quality with a few noticeable weeds, and 10 represented best plot quality with no weeds.

Visual quality of ornamental plants was assessed at 4,8 , and 12 WAT. Ratings on a scale from 1 to 10 were assigned to each plant considering plant size ( 3 points), foliage

Table 1. Particle size composition and bulk density of pine nugget, pine straw, and shredded cypress mulch.

\begin{tabular}{lcccc}
\hline & \multicolumn{3}{c}{ Particle size (length) $^{\mathrm{z}}$} & \\
\cline { 2 - 4 } Mulch product & $\begin{array}{c}\text { < inch } \\
(\% \mathbf{~ v o l})\end{array}$ & $\begin{array}{c}\mathbf{1} \text { to } \mathbf{2} \text { inch } \\
(\% \mathbf{~ v o l})\end{array}$ & $\begin{array}{c}>\mathbf{2} \text { inch } \\
(\% \text { vol })\end{array}$ & $\begin{array}{c}\text { Bulk density } \\
\left(\mathbf{g} \cdot \mathbf{L}^{-\mathbf{1}}\right)^{\mathbf{y}}\end{array}$ \\
\hline Shredded cypress & 32.8 & 57.7 & 9.5 & 215.1 \\
Pine nugget & 8.6 & 62.5 & 28.9 & 187.8 \\
Pine straw & 2 & 5 & 93 & 63.0 \\
\hline
\end{tabular}

${ }^{2} 1$ inch $=2.54 \mathrm{~cm}$.

${ }^{\mathrm{y}} \mathrm{g} \cdot \mathrm{L}^{-1}=0.1335 \mathrm{oz} / \mathrm{gal}$. greenness ( 3 points), foliage fullness ( 2 points $)$, and flowering ( 2 points). A rating of 1 represented dead plants. Ratings from 2 to 3 represented poor quality with plants exhibiting severe phytotoxicity or nutrient deficiency symptoms. Ratings from 4 to 5 represented below-average quality with plants exhibiting phytotoxicity or nutrient deficiency symptoms. Ratings from 6 to 7 represented average qualities, and ratings from 8 to 9 represented good quality. A rating of 10 represented premium plant quality with large plant size, dense and dark green leaves, and abundant flowers. Two horticulturists conducted visual quality assessment independently, and data were pooled before analysis.

A separate visual rating was made on gardenia when leaf chlorosis (LC) was observed at 4 WAT. Leaf chlorosis was rated on a scale of 0 to 5 where 0 represented no yellowing leaves, 1 represented $1 \%$ to $5 \%$ leaves on a plant turned yellow, 2 represented $6 \%$ to $10 \%, 3$ represented $11 \%$ to $20 \%, 4$ represented $21 \%$ to $30 \%$, and 5 represented $40 \%$ or more leaves on a plant had become yellow.

Number of flowers was recorded for gardenia and daylily at 8,12 , and 17 WAT. A daylily flower was counted when its outer three petals were partially reflexed. A gardenia flower was counted when its first layer of petals unfolded to reveal center petals.

At 17 WAT, daylily, gardenia, and liriope plants were measured for height $(\mathrm{H}$, measured from soil surface to the tallest point of the plant excluding inflorescences), widest width $\left(\mathrm{W}_{1}\right)$, and the width perpendicular to the widest width $\left(\mathrm{W}_{2}\right)$. Size index was calculated as $\mathrm{SI}=\left(\mathrm{H}+\mathrm{W}_{1}+\mathrm{W}_{2}\right) / 3$. Aboveground parts of one randomly selected daylily and liriope in each plot were harvested and dried in an oven at $70{ }^{\circ} \mathrm{C}$ for $48 \mathrm{~h}$ to achieve constant weight, and weighed. At 26 WAT, daylily and the remaining gardenia and liriope plants were measured for size, and aboveground parts of daylily and liriope plants were harvested for determining biomass.

Statistical analysis. Shoot density, percentage control, plant growth, and flower number were analyzed as numerical data. Plot aesthetic quality, plant visual quality, and LC were analyzed as categorical data. All data were subjected to normality control and those that failed were 
transformed using appropriate means to improve normality (Hartwig and Dearing, 1979). LSMEANS were back-transformed after analysis. Rather than using repeated measurement analysis, because of interactions between treatments and sample dates, repeated measurements such as shoot density were analyzed by each sample date.

Treatment structure was an unbalanced factorial because mulchalone and herbicide-alone treatments did not have herbicide placement as one of the three treatment factors. PROC GLIMMIX was used when an analysis included all treatment factors: mulch type (four levels), herbicide rate (three levels), and placement (two levels) (SAS version 9.3; SAS Institute, Cary, NC). In this model, treatment factors and their interactions were considered fixed effects. Block, block $\times$ mulch type $\times$ rate, and block $\times$ mulch type $\times$ rate $\times$ placement were considered random effects (O'Rourke et al., 2005). Means were compared using LSMEAN PDIFF. An additional software was performed after each PDIFF command to assist the grouping of the LSMEANS (Saxton, 1998). Value of alpha in the original coding of this software was changed to 0.05 . When interactions between placement and other factors were not significant, data were reanalyzed with PROC MIXED and LSMEAN statements. The LSMEANS were separated using Tukey's honestly significant difference test. Singlevariable linear regression analysis (criterion for inclusion $P=0.05$ ) was performed using yellow nutsedge shoot density (at 12 WAT) as the predictor variable and PAQ as the dependent variable.

\section{Results}

Responses of yellow nutsedge and ornamental plants to mulching and herbicide treatments varied over time and are presented by sample dates.

Shoot density in untreated bare soil plots increased from 1.9 to 11.2 shoots $/ \mathrm{ft}^{2}$ by 12 WAT (Fig. 1). Shoot densities were $40 \%$ to $60 \%$ less and significantly different in mulch-alone plots compared with untreated, bare soil plots. However, by 12 WAT, yellow nutsedge shoot density increased to an unacceptable level in all mulchalone plots (6.5 to 6.7 shoots $/ \mathrm{ft}^{2}$ ).

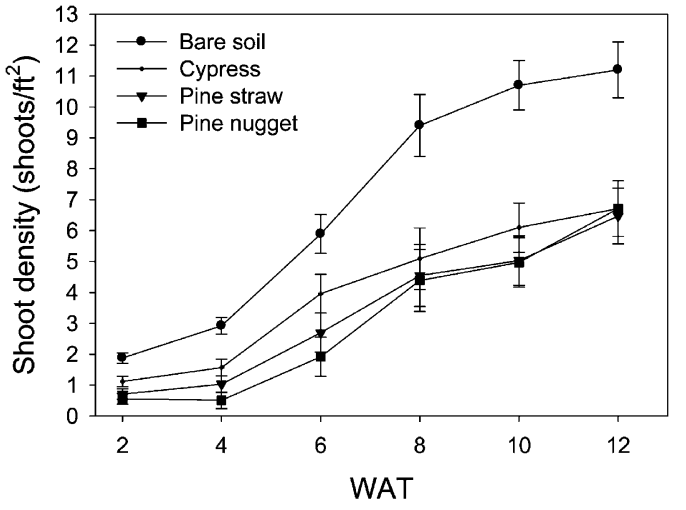

Fig. 1. Yellow nutsedge shoot density in untreated bare soil and mulch-alone plots from 2 to 12 weeks after treatments (WAT) with s-ethyl dipropylthiocarbamate (EPTC). Bars are SE for treatment comparison at each sample date; 1 shoot $/ \mathrm{ft}^{2}=$ 10.7639 shoots $/ \mathrm{m}^{2}$.

These results indicate that mulching can provide some yellow nutsedge control but was inadequate in maintaining plot quality.

Interaction of herbicide rate $x$ mulch type $\times$ placement was not significant for shoot density in mulch + herbicide treatments. Significant interactions were found between mulch type and herbicide placement or between herbicide rate and placement at all sample dates. Therefore, results are presented for treatment combinations at each sample date (Fig. 2).

MULCH $\times$ HERBICIDE PLACEMENT INTERACTION. Yellow nutsedge shoot density was generally lesser when EPTC was applied under mulch compared with above-mulch applications. This placement effect was greater with shredded cypress at both EPTC rates, but lesser for pine straw and pine nugget mulches (Fig. 2). As a result, yellow nutsedge shoot density was lesser in plots treated with EPTC under shredded cypress than all other treatments throughout the 12 -week evaluation period.

Herbicide RATE $\times$ PLACEMENT inTERACTION. High rate of EPTC did not further reduce shoot density over low rate when applied under mulch at most sample dates. Thus, using low rate of EPTC when applied under mulch can provide similar control as high rate regardless of mulch products. When applied above mulch, high rate further reduced shoot density in pine straw at all sample dates, in shredded cypress at 6 WAT and thereafter, but not in pine nuggets (Fig. 2). At 12 WAT, EPTC at both rates applied under shredded cypress resulted in the lowest shoot density and received PAQ > 9 (PAQ data not shown). Next least shoot density occurred when high EPTC rate was applied under pine nugget mulch.

Regression analysis revealed that PAQ was negatively affected by weed presence, and there was a linear relationship between the two $\left[r^{2}=0.78\right.$ (Fig. 3)]. Based on this relationship, plots having no yellow nutsedge received an average PAQ of 9.1, and plots having $>1.6$ shoots $/ \mathrm{ft}^{2}$ were rated $<8$ and considered unacceptable for a well-maintained landscape bed.

Herbicide rate $\times$ placement interaction was significant across mulch type for PAQ at 12 WAT. PAQ was greater when EPTC was applied under mulch than above mulch at low rate. However, this placement effect was not significant at the high rate (Fig. 4). When comparing individual treatments, plots treated with EPTC at low rate under shredded cypress or nugget, and at high rate under all three mulches or above shredded cypress had acceptable quality at 12 WAT (PAQ $>8$, data not shown).

At 17 WAT, yellow nutsedge control efficacy was visually estimated as percentage control relative to untreated bare soil plots $(0 \%$ control $)$ (Fig. 5). Across mulch type and placement, high EPTC rate did not provide greater control compared with low rate except when applied under pine nugget. The EPTC at both rates applied under shredded cypress or high rate applied under pine nugget provided the greatest controls $(\geq 90 \%)$. These results are consistent with those 

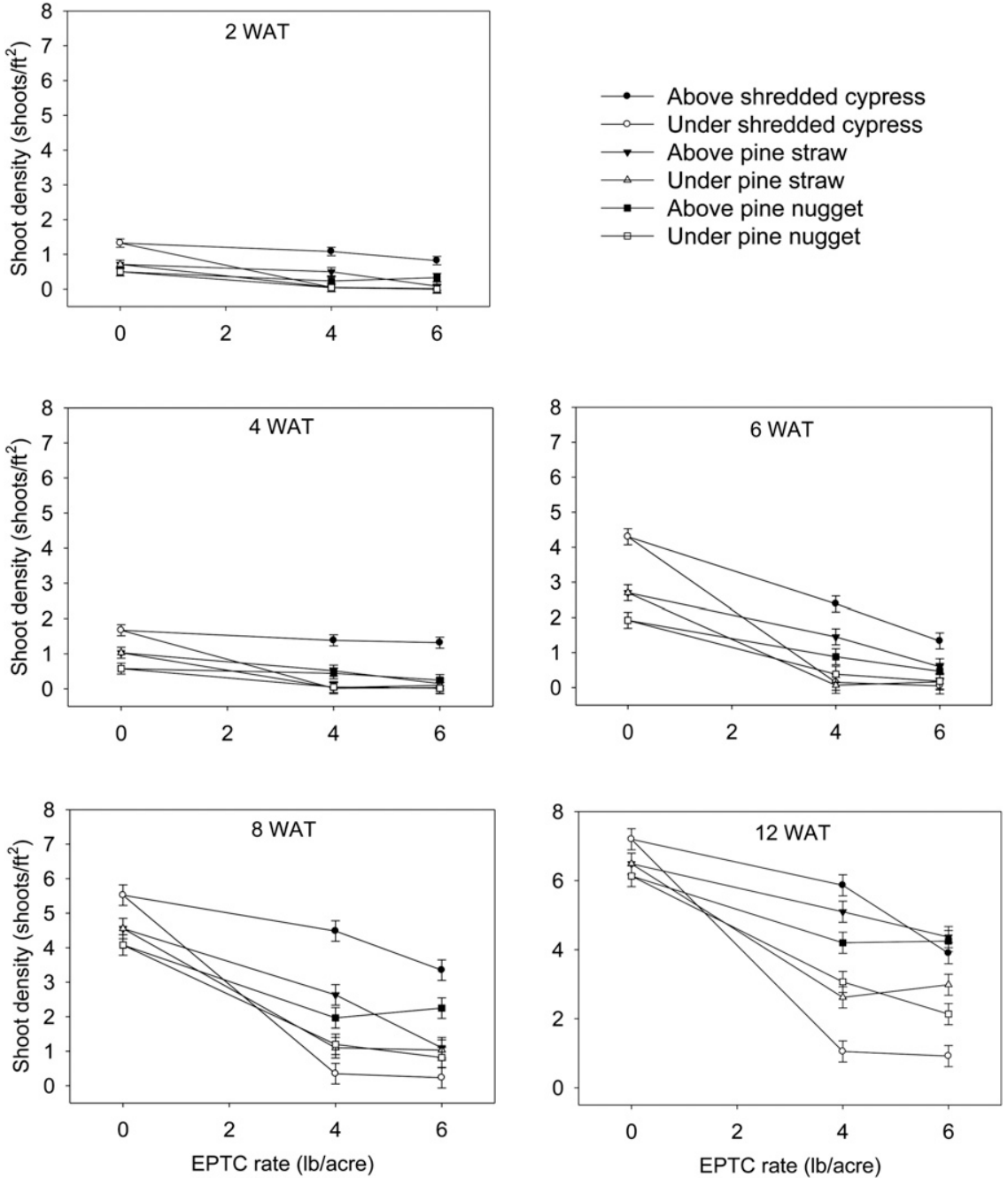

Fig. 2. Yellow nutsedge shoot density at 2, 4, 6, 8, and 12 weeks after treatments (WAT) with s-ethyl dipropylthiocarbamate (EPTC) at 0,4 , or $6 \mathrm{lb} /$ acre $(0=$ water $)$ applied under or above pine nugget, pine straw, or shredded cypress mulches. Plotted points are means of four replications and bars represent SE for comparing treatments at each sample date; $1 \mathrm{lb} /$ acre $=1.1209 \mathrm{~kg} \cdot \mathrm{ha}^{-1}, 1 \mathrm{shoot} / \mathrm{ft}^{2}=10.7639$ shoots $/ \mathrm{m}^{2}$.

observed with shoot densities at 12 WAT.

No visual injury to leaves was observed in daylily or liriope. Leaf chlorosis in gardenia was the only symptom observed that was potential herbicide injury during the experiment. Leaf chlorosis ratings at 4 WAT indicated no interaction among treatment factors, and EPTC did not affect the degree of chlorosis (Table 2). Most chlorosis began in bottom leaves and progressed upward, indicating a possible symptom of plant response to environmental stresses. Compared with plants in untreated bare soil plots, plants in pine straw and pine nugget mulched plots had less severe chlorosis, thus mulching may have alleviated transplant stress.

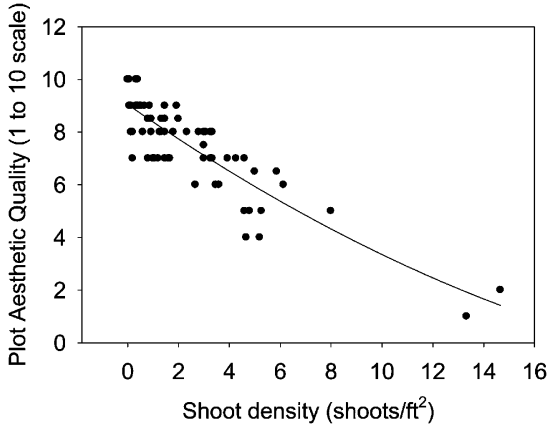

Fig. 3. Field plot aesthetic quality ratings (PAQ) for s-ethyl dipropylthiocarbamate (EPTC)treated plots at 12 weeks after treatment application against yellow nutsedge density $(y=9.05-0.68$ $\left.x+0.01 x^{2}, r^{2}=0.78, P<0.0001\right)$. PAQ was assigned to a plot based on weed presence on a scale from 1 to 10 , where 1 to 3 = the most severe weed infestations (e.g., in untreated bare soil plots), 4 to 5 = poor plot quality with severe weed infestation, 6 to $7=$ belowaverage quality with unacceptable weed presence, $8=$ average quality with some weeds, $9=$ good quality with a few weeds, and 10 = best plot quality with no weed; 1 shoot $/ \mathrm{ft}^{2}=10.7639$ shoots $/ \mathrm{m}^{2}$.

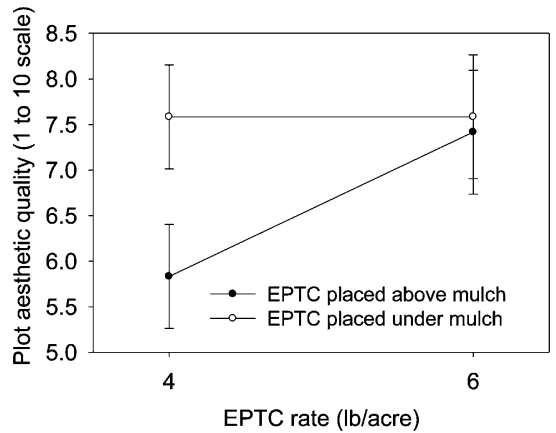

Fig. 4. Plot aesthetic quality (PAQ) at 12 weeks after s-ethyl dipropylthiocarbamate (EPTC) treatments at 4 or $6 \mathrm{lb} /$ acre either above or under mulches. Ratings were averaged across mulch products (pine nugget, pine straw, and shredded cypress). PAQ was assigned to a plot based on weed presence on a scale from 1 to 10 , where 1 to $3=$ the most severe weed infestations (e.g., in untreated bare soil plots), 4 to 5 = poor plot quality with severe weed infestation, 6 to $7=$ below-average quality with unacceptable weed presence, 8 = average quality with some weeds, 9 = good quality with a few weeds, and $10=$ best plot quality with no weed. Plotted points are means of 12 replications. Bars represent SE; $1 \mathrm{lb} /$ acre $=1.1209 \mathrm{~kg} \cdot \mathrm{ha}^{-1}, 1$ shoot $/ \mathrm{ft}^{2}=$ 10.7639 shoots $/ \mathrm{m}^{2}$. 
compared with daylilies in shredded cypress- or pine straw-mulched plots. Aboveground biomass was least in pine nugget-mulched plots but only less than those in cypress-mulched plots. These differences were not significant at 26 WAT (data not shown).

Liriope flowered at $8 \mathrm{WAT}$, and overall quality at 12 WAT and plant size at 17 and 26 WAT were unaffected by any treatment factors (data not shown). Liriope biomass was unaffected by herbicide, but was less in mulched plots than those in herbicide-alone plots, suggesting that liriope growth might have been affected by mulching (Table 2). At 26 WAT, plant size and biomass of liriope was similar across treatments (data not shown).

\section{Discussion}

Plot aesthetic quality ratings indicated that yellow nutsedge at mature size can reduce the visual quality of a mulched landscape bed at very low densities (i.e., 1.6 shoots $/ \mathrm{ft}^{2}$ ). Considering this and the ability of

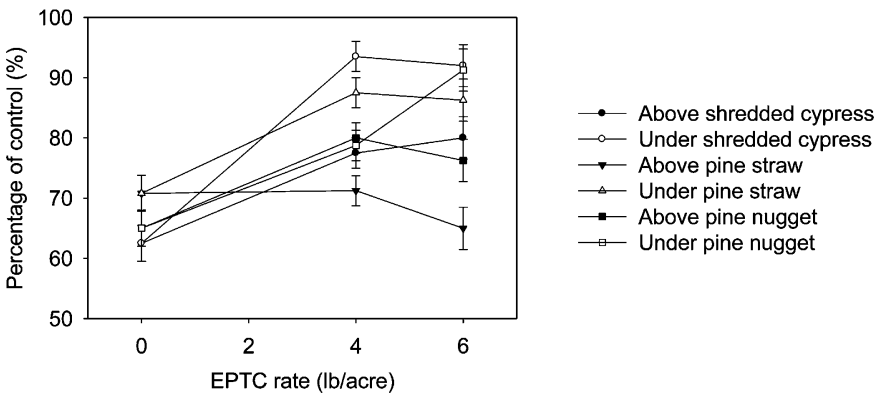

Fig. 5. Visual estimation of yellow nutsedge control at 17 weeks after s-ethyl dipropylthiocarbamate (EPTC) treatment application at 0,4 or $6 \mathrm{lb} /$ acre either above or under pine nugget, pine straw, or shredded cypress mulches. The visual estimation had a scale from $0 \%$ to $100 \%$ (complete control) relative to weed presence in untreated bare soil plots $(0 \%$, no control). Plotted points are means of four replications and bars represent SE for comparing treatments; $1 \mathrm{lb} /$ acre $=1.1209$ $\mathrm{kg} \cdot \mathrm{ha}^{-1}$.

yellow nutsedge to make numerous tubers once mature (Ransom et al., 2009), controlling tuber emergence and early growth is critical for a successful yellow nutsedge control program.

Authors found that relative to bare soil, mulching provided $40 \%$ to $60 \%$ yellow nutsedge control, similar to those presented in previous studies evaluating weed control effects of organic mulches (Broschat, 2007; Chalker-Scott, 2007). As shown in this study, the three mulches tested provided different degrees of yellow nutsedge control, and shredded cypress, pine straw, and pine nugget maintained acceptable plot quality for 4,5 , and 6 weeks, respectively. Differences in physical and chemical properties among mulch products may have affected their weed control abilities. Findings by Duryea et al. (1999) in a study on allelopathic properties of mulches reported that all mulches had some degree of allelopathy when materials were fresh and ranked their effects on weeds as pine straw $>$ pine bark $>$ shredded cypress. In this study, greater yellow nutsedge control was found with pine nugget in some plots perhaps because of its larger size than pine bark that may have provided more light exclusion, an important factor in yellow nutsedge

Table 2. Leaf chlorosis, number of flower, and visual quality of 'Mystery' gardenia; number of flower, visual quality, size index (SI), and aboveground biomass [dry weight (DW)] of 'Stella de Oro' daylily; and biomass of 'Big Blue' liriope at various weeks after treatment (WAT) with s-ethyl dipropylthiocarbamate (EPTC) at 0,4 , or $6 \mathrm{lb} / \mathrm{acre}(0=$ water $)$ applied above or under pine nugget, pine straw, shredded cypress mulches or on bare soil.

\begin{tabular}{|c|c|c|c|c|c|c|c|c|}
\hline \multirow[b]{2}{*}{ Treatment $^{\mathrm{z}}$} & \multicolumn{3}{|c|}{ Gardenia } & \multicolumn{4}{|c|}{ Daylily } & \multirow{2}{*}{$\begin{array}{l}\text { Liriope } \\
\text { DW (g) } \\
\text { 17 WAT }\end{array}$} \\
\hline & $\begin{array}{c}\begin{array}{c}\text { Leaf } \\
\text { chlorosis } \\
(0-5 \text { scale })^{\mathrm{y}}\end{array} \\
4 \text { WAT }\end{array}$ & $\begin{array}{l}\text { Flowers } \\
\frac{(\text { no. })^{\mathrm{x}}}{8 \mathrm{WAT}}\end{array}$ & $\begin{array}{c}\begin{array}{c}\text { Visual } \\
\text { quality } \\
(1-10 \text { scale })^{\mathrm{w}}\end{array} \\
12 \text { WAT }\end{array}$ & $\begin{array}{c}\text { Flowers } \\
(\text { no. })^{v} \\
\text { 8WAT }\end{array}$ & $\begin{array}{c}\begin{array}{c}\text { Visual } \\
\text { quality } \\
(1-10 \text { scale })\end{array} \\
12 \text { WAT }\end{array}$ & $\frac{S I(\mathrm{~cm})^{\mathrm{u}}}{17 \mathrm{WAT}}$ & $\frac{\mathrm{DW}(\mathrm{g})^{\mathrm{t}}}{17 \mathrm{WAT}}$ & \\
\hline \multicolumn{9}{|l|}{ EPTC rate (lb/acre) } \\
\hline 0 (Mulch-alone) & 2.3 & $6.5 b^{s}$ & 8.2 & 0.7 & 8.3 & 27.6 & $1.83 \mathrm{~b}$ & 8.07 \\
\hline \multicolumn{9}{|l|}{ Mulch type } \\
\hline Bare soil (herbicide-alone) & $3.7 \mathrm{a}$ & $1.5 \mathrm{c}$ & $7.1 \mathrm{~b}$ & $1.2 \mathrm{a}$ & 8.1 & $21.9 \mathrm{~b}$ & $1.99 \mathrm{ab}$ & $12.48 \mathrm{a}$ \\
\hline Shredded cypress & $2.7 \mathrm{ab}$ & $6.3 \mathrm{bc}$ & $8.3 \mathrm{a}$ & $1.1 \mathrm{ab}$ & 8.6 & $26.4 \mathrm{a}$ & $2.66 \mathrm{a}$ & $8.15 \mathrm{~b}$ \\
\hline Pine nugget & $2.4 \mathrm{~b}$ & $7.6 \mathrm{ab}$ & $8.5 \mathrm{a}$ & $0.9 \mathrm{ab}$ & 8.4 & $23.6 \mathrm{ab}$ & $1.66 \mathrm{~b}$ & $7.19 \mathrm{~b}$ \\
\hline Pine straw & $2.5 \mathrm{~b}$ & $12.1 \mathrm{a}$ & $8.4 \mathrm{a}$ & $0.5 \mathrm{~b}$ & 8.7 & $26.2 \mathrm{a}$ & $2.03 \mathrm{ab}$ & $8.27 \mathrm{~b}$ \\
\hline
\end{tabular}

${ }^{2}$ No significant interaction among treatment factors was found with any of the dependent variables measured on ornamental plants

${ }^{y}$ Leaf chlorosis was rated with a scale of 0 to 5 , where $0=$ no yellowing, $1=1 \%$ to $5 \%$ yellowing, $2=6 \%$ to $10 \%, 3=11 \%$ to $20 \%, 4=21 \%$ to $30 \%$, and $5=40 \%$ or $\mathrm{more}$.

xA gardenia flower was counted when the first layer of the petals unfolded to reveal center petals.

wisual quality ratings on a scale from 1 to 10 were assigned to each plant considering plant size ( 3 points), foliage greenness ( 3 points), foliage fullness ( 2 points), and flowering

( 2 points), where $10=$ excellent quality, 8 to $9=\operatorname{good}, 6$ to $7=$ average, 4 to $5=$ below average, 2 to $3=$ poor, and $1=$ dead

vA daylily flower was counted when the outer three petals were partially reflexed.

uSize index $=\left(\mathrm{H}+\mathrm{W}_{1}+\mathrm{W}_{2}\right) / 3$, where $\mathrm{H}$ is plant height, $\mathrm{W}_{1}$ is the widest width, and $\mathrm{W}_{2}$ is the width perpendicular to the widest width; $\mathrm{l} \mathrm{cm}=0.3937$ inch.

${ }^{\mathrm{t}} \mathrm{lg}=0.0353 \mathrm{oz}$.

${ }^{\mathrm{s}}$ Mean separation within columns for herbicide rates across mulch type and herbicide placement (where applicable) by using Tukey's honestly significant difference (HSD) test at $\alpha \leq 0.05$. Means without letter denotes no significant differences among treatments were found.

$\mathrm{l} \mathrm{lb} /$ acre $=1.1209 \mathrm{~kg} \cdot \mathrm{ha}^{-1}$. 

(1999) also reported once the mulches are "weathered" after l year, weed growth was found similar among all mulches. Duration of this study was not long enough to observe this effect; however, industry practice of replenishing beds with fresh mulch at least once per year can take advantage of this allelopathic effect offered by mulching.

EPTC applied as preemergence herbicide controlled yellow nutsedge in all treated plots, which was consistent with the control efficacy reported from other field crops (e.g., Ahrens, 1994). In this study, herbicide placement had significant effect on EPTC efficacy. EPTC applied under mulch resulted in greater control than applying above at most sample dates. Data presented by Samtani et al. (2007) suggested that herbicidesprayed mulch may act as slow release carrier for selected preemergence herbicides. In their study, flomioxazintreated hard wood bark or pine nuggets increased and extended herbicide efficacy and reduced ornamental plant phytotoxicity. cide (Baker et al., 1996). Abu-Qare and Duncan (2002) reported rapid degradation of EPTC in methanol and water solutions after irradiated with ultraviolet light at $254 \mathrm{~nm}$. Thus, lower light intensity under mulches may have reduced degradation speed compared with applying above mulches (Table 3). In this study, the most significant improvement in control efficacy from applying under mulch was found with shredded cypress, which had the lowest underneath light intensity among the three mulches.

EPTC at high rate resulted in similar control as low rate when applied germination (Table 3). Duryea et al.

EPTC is a highly volatile herbi-

under mulches. Therefore, applying under mulch can reduce rate needed for efficacy. In addition, although no acute injury was observed in this study, lower rates may reduce the chance of phytotoxicity to sensitive plants. Based on these preliminary data, authors recommend EPTC be applied under mulch when establishing new landscape beds, especially when shredded cypress mulch is used. For existing landscape beds, it would be beneficial to apply EPTC before replenishing the bed with new mulch materials.

Authors reported no adverse effect from EPTC on the growth and quality of 'Mystery' gardenia, 'Stella de Oro' daylily, and 'Big Blue' liriope. These ornamental plants were selected in this study because they are commonly used in the southeastern United States and have been tested in phytotoxicity studies with other herbicides. Gardenia has been reported to tolerate several preemergence herbicides registered for nursery or landscape use, such as flumioxazin (Richardson et al., 2008), oxyfluorfen (Lamont 1983), or oxadiazon and metolachlor (Crossan et al., 1996). Daylilies were reported to tolerate several preemergence herbicides. Melton et al. (1989) reported that daylily photosynthesis was unaffected by herbicide bentazone. Bare root daylilies of an unknown cultivar tolerated label rates of metolachlor, pendimethalin, pronamide, and oxyfluorfen (Zheljazkov et al., 2007). However, bleached spots and necrotic leaves were reported in 'Aztec Gold' daylilies grown in containers and treated with oxadiazon (Norcini and Aldrich, 1992), or combinations of oryzalin + oxyfluorfen and pendimethalin + oxyfluorfen (Stamps and Neal, 1990). A vigorous daylily,

Table 3. Maximum, minimum, and daily average temperatures, and soil moisture (volumetric water content) at 1 inch $(2.54 \mathrm{~cm})$ below bedding mix surface in plots mulched with pine nugget, pine straw, or shredded cypress, or bare soil, and light intensity at the surface of bedding mix under each mulch product or at the surface of bare soil. Temperatures and soil moisture were recorded from 0700 to $0800 \mathrm{HR}, 6$ to 13 June 2006. Light intensities were measured at $1200 \mathrm{HR}$ 6 to 13 June 2006.

\begin{tabular}{lccccc}
\hline Mulch type & $\begin{array}{c}\text { Maximum } \\
\operatorname{temp}\left({ }^{\circ} \mathbf{F}\right)^{\mathbf{z}}\end{array}$ & $\begin{array}{c}\text { Minimum } \\
\operatorname{temp}\left({ }^{\circ} \mathbf{F}\right)\end{array}$ & $\begin{array}{c}\text { Avg } \\
\operatorname{temp}\left({ }^{\circ} \mathbf{F}\right)\end{array}$ & $\begin{array}{c}\text { Light intensity } \\
\left(\boldsymbol{\mu m o l} \cdot \mathbf{m}^{-2} \cdot \mathbf{s}^{-1}\right)\end{array}$ & $\begin{array}{c}\text { Soil } \\
\text { moisture } \\
(\mathbf{M P a})^{\mathbf{y}}\end{array}$ \\
\hline Shredded cypress & 85 & 78 & 81.5 & 133 & -0.069 \\
Pine nugget & 86 & 78 & 82 & 162 & -0.044 \\
Pine straw & 86 & 77 & 81.5 & 170 & -0.032 \\
Bare soil & 92 & 71 & 81.5 & 1475 & -0.030 \\
\hline
\end{tabular}

${ }^{z}\left({ }^{\circ} \mathrm{F}-32\right) \div 1.8={ }^{\circ} \mathrm{C}, 1 \mathrm{MPa}=10$ bar.
'Young Love' was reported to be more tolerant to pre- and postemergence herbicides than less vigorous cultivar After Dark (Calkins et al., 1996). Response of 'Big Blue' liriope to preemergence herbicides has not been reported in previous studies.

Authors reported positive effects of mulching on gardenia transplant stress as evidenced by less severe LC, more flowers and greater visual quality in mulched plots compared with unmulched plots. In addition, daylily plant size responded positively to shredded cypress and pine straw compared with herbicide-alone (no mulch), although overall plant visual quality did not improve. Similar results have been reported with gardenia cultivar August Beauty (Richardson et al., 2008 ), in which growth was slightly improved when mulched with mini pine bark nuggets. These positive effects may be attributed to less fluctuation in soil temperature or higher soil moisture in mulched plots (Table 3 ). Although soil nutrient concentrations were not analyzed in this study, it was reported that shredded cypress mulch increased soil potassium concentration, and pine bark and eucalyptus mulch increased soil magnesium concentrations over unmulched plots (Broschat, 2007).

Mulching reduced liriope biomass, although visual qualities were unaffected. Similar adverse effects were reported for ligustrum (Ligustrum japonicum) that plants were smaller when mulched with 4 -inch pine bark compared with those in unmulched plots, and plant size decreased with increasing mulch depth (Billeaud and Zajicek, 1989).

Based on these preliminary results, EPTC applied as a preemergence herbicide can effectively control yellow nutsedge and maintain PAQ for up to 12 weeks when applied under mulch at $4 \mathrm{lb} /$ acre or up to 6 weeks when applied above mulch. No acute injury or growth and quality reduction were found from overhead application of EPTC in selected ornamental plants. This granular formulation has the potential to be an effective preemergence tool for yellow nutsedge management in landscape beds.

\section{Literature cited}

Abu-Qare, A.W. and H.J. Duncan. 2002. Photodegradation of the herbicide EPTC 
and the safener dichlormid, alone and in combination. Chemosphere 46:11831189.

Ahrens, J. 1994. Control of yellow nutsedge in nursery plantings. Proc. Northeastern Weed Sci. Soc. 33:223-227.

Baker, J.M., W.C. Koskinen, and R.H Dowdy. 1996. Volatilization of EPTC: Simulation and measurement. J. Environ. Qual. 25:169-177.

Banks, P.A. 1983. Yellow nutsedge (Cyperus esculentus) control, regrowth, and tuber production as affected by herbicides. Weed Sci. 31:419-422.

Bilderback, T.E. and W.C. Fonteno. 1993. Impact of hydrogel on physical properties of coarse-structured horticultural substrates. J. Amer. Soc. Hort. Sci. 118:217-222.

Billeaud, L.A. and J.M. Zajicek. 1989. Influence of mulches on weed control, soil $\mathrm{pH}$, soil nitrogen content, and growth of Ligustum japonicum. J. Environ. Hort. 7:155-157.

Broschat, T.K. 2007. Effects of mulch type and fertilizer placement on weed growth and soil $\mathrm{pH}$ and nutrient content. HortTechnology 17:174-177.

Calkins, J.B., B.T. Swanson, and D.L. Newman. 1996. Weed control strategies for field grown herbaceous perennials. J. Environ. Hort. 14:221-227.

Case, L.T., H. Mathers, and A.F. Senesac. 2005. A review of weed control practices in container nurseries. Hort Technology $15: 535-545$.

Chalker-Scott, L. 2007. Impact of mulches on landscape plants and the environment - A review. J. Environ. Hort. 25:239-249.

Cregg, B.M. and R. Schutzki. 2009. Weed control and organic mulches affect physiology and growth of landscape shrubs. HortScience 44:1419-1424.

Crossan, C.K., C.H. Gilliam, D.J. Eakes, G.J. Keever, G.R. Wehtje, and W.A. Dozier. Jr. 1996. Weed control with herbicide-coated or -blended fertilizer in August Beauty gardenia. J. Environ. Hort. $14: 5-8$.

Duryea, M.L., R.J. English, and L.A. Hermansen. 1999. A comparison of landscape mulches: Chemical, allelopathic, and decomposition properties. J. Arboricult. 25:88-96.

Gao, G.Y., J.F. Boggs, P.J. Bennett, J.C. Martin, J.A. Chatfield, M.A. Rose, J.W Rimelspach, R.H. Zondag, J.R. Street, and W.E. Pound. 1999. Weed problems in Ohio turf, landscapes, and nurseries. Ohio Agr. Res. Dev. Ctr. Spec. Circ. 165:55-58.

Gilman, E.F. and J. Grabosky. 2004. Mulch and planting depth affect live oak establishment. J. Arboricult. 30:311317.

Green, T.L. and G.W. Watson. 1989. Effects of turfgrass and mulch on the establishment and growth of bare-root sugar maples. J. Arboricult. 15:268-272.

Hartwig, F. and B.E. Dearing. 1979. Looking at data: Distributions of single variables, p.13-30. In: F. Hartwig and B.E. Dearing (eds.). Exploratory data analysis. Sage Publ., Newberry Park, CA.

Hensley, D. 1990. Creative landscaping for water conservation. Nursery Manager 6(9):83.

Hild, A.L. and D.L. Morgan. 1993. Mulch effects on crown growth of five southwestern shrub species. J. Environ. Hort. 11:41-43.

Lamont, G.P. 1983. Pre-emergent herbicides for weed control in pots. Rural Nwsl. $87: 16-18$

Maggard, A.O., R.E. Will, T.C. Hennessey, C.R. McKinley, and J.C. Cole. 2012. Treebased mulches influence soil properties and plant growth. HortTechnology 22:353361.

Melton, R., J. Kelly, and T. Whitewll. 1989. Physiological response of hosta, daylily, and yellow nutsedge to bentazone. HortScience 24:1009-1010.

Norcini, J.G. and J.H. Aldrich. 1992. Spotted spurge control and phytotoxicity to daylily from preemergence herbicides. J. Environ. Hort. 10:14-17.

O'Rourke, N., L. Hatcher, and E.J. Stepanksi. 2005. Using the LSMEANS statement to analyze data from unbalanced designs. In: A Step-by-step approach to using $S A S^{\circledR}$ for univariate \& multivariate statistics. 2nd ed. SAS Institute, Cary, NC.

Patton, A. and K. Daniel. 2012. Yellow nutsedge control in turf and ornamentals.
Indiana Nursery Landscape News 72(4): 26-27.

Pickering, J.S. and A. Shepherd. 2000. Evaluation of organic landscape mulches: Composition and nutrient release characteristics. J. Arboricult. 24:175-187.

Ransom, C.V., C.A. Rice, and C.C. Shock. 2009. Yellow nutsedge (Cyperus esculentus) growth and reproduction in response to nitrogen and irrigation. Weed Sci. 57:21-25.

Richardson, B., C.H. Gilliam, G. Gain, and G. Wehtje. 2008. Nursery container weed control with pinebark mini-nuggets. J. Environ. Hort. 26:144-148.

Samtani, J.B., G.J. Kling, H.M. Mathers, and L. Case. 2007. Rice hulls, leaf-waste pellets, and pine bark as herbicide carriers for container-grown woody ornamentals. HortTechnology 17:289-295.

Saxton, A.M. 1998. A macro for converting mean separation output to letter groupings in ProcMixed, p. 1243-1246. In: Proc. 23rd SAS User Group Intel. Conf., Nashville, TN. 22-25 Mar. 1998. SAS Inst., Cary, NC.

Siczek, A. and M. Frac. 2012. Soil microbial activity as influenced by compaction and straw mulching. Intl. Agrophysics 26:65-69.

Skroch, W.A., M.A. Powell, T.E. Bilderback, and P.H. Henry. 1992. Mulches: Durability, aesthetic value, weed control, and temperature. J. Environ. Hort. 10:4345 .

Stamps, R.H. and C.A. Neal. 1990. Evaluation of dinitroaniline herbicides for weed control in container landscape plant production. J. Environ. Hort. 8:52-57.

Stoller, E.W. and R.D. Sweet. 1987. Biology and life cycle of purple and yellow nutsedge (Cyperus rotundus and C. esculentus). Weed Technol. 1:66-73.

Wilcut, J.W., C.H. Gilliam, G.R. Wehtje, T.V. Hicks, and D.L. Berchielli. 1991. Yellow nutsedge control in landscape plants. HortScience 26:159-162.

Zheljazkov, V.D., K. Patterson, K.J. Parsons, and G. Sampson. 2007. Tolerance of bareroot ornamental perennials to selected herbicides. Can. J. Plant Sci. 87:439442 . 